\title{
2 Termites and flooding affect microbial communities in decomposing wood
}

3 Michael D. Ulyshen ${ }^{1^{*}}$, Susan V. Diehl ${ }^{2}$ and Dragica Jeremic ${ }^{2}$

4

$5 \quad{ }^{1}$ USDA Forest Service, Southern Research Station, Athens GA USA

$6 \quad{ }^{2}$ Mississippi State University, Department of Sustainable Bioproducts, Starkville MS USA

7

$8 \quad *$ corresponding author: mulyshen@ fs.fed.us

9

10 Abstract

11

12 Wood properties and microbial community characteristics were compared between loblolly pine (Pinus taeda L.)

13 logs protected or unprotected from termites (Blattodea: Rhinotermitidae: Reticulitermes spp.) and other arthropods

14 for two years in seasonally flooded and unflooded forests in the southeastern United States. Significant

15 compositional differences were observed between treatments and between flood patterns for both bacterial and

16 fungal communities. Bacteria were 8 to 9 -fold more abundant in unprotected logs compared to protected logs in both

17 flooded and unflooded forests, with the greatest abundance seen in unprotected and unflooded logs. Wood nitrogen

18 and lignin contents were unaffected by treatment, flood pattern or levels of termite damage visible in unprotected

19 logs. We conclude that termites alter the composition of both bacterial and fungal communities and thus have the

20 potential to indirectly affect wood decomposition and related processes through interactions with the microbial

21 community.

22

23 Keywords coarse woody debris, decomposition, Isoptera, saproxylic, T-RFLP

24

\section{1. Introduction}

26

C 2016. This manuscript version is made available under the Elsevier user license

http://www.elsevier.com/open-access/userlicense/1.0/ 
27 Wood decomposition is largely driven by microbes capable of producing the enzymes necessary to digest cellulose and lignin. Although the activities of these organisms are largely controlled by physical conditions such as temperature, moisture and substrate chemistry, decomposition models based on physical conditions alone rarely explain more than $75 \%$ of the variation in observed decay rates (Adair et al., 2008; Gholz et al., 2000; Liu et al., 2013; Meentemeyer, 1978; Moorhead et al., 1999; Trofymow et al., 2002). Differences in microbial community composition, richness and assembly history potentially explain much of the remaining variation (van der Wal et al., 2013; van der Wal et al., 2015). For example, Fukami et al. (2010) caused three-fold differences in fungal species richness and decay rates by manipulating the arrival order of fungal colonists. Although randomness no doubt plays an important role in the arrival order of fungi under natural conditions, these communities may be influenced by the activities of other organisms as well. Many insect species share decomposing wood with microbes, for example, and interactions between these organisms are predicted to alter decomposer communities and wood decomposition rates (Jacobsen et al., 2015; Ulyshen, 2016; Ulyshen et al., 2016). There are a number of potential mechanisms by which invertebrates may alter microbial communities in decomposing wood. Some beetle species have been shown to facilitate fungal colonization by vectoring spores (Strid et al., 2014) or by creating tunnels into wood (Leach et al., 1937). Other invertebrates are thought to influence interspecific interactions between fungi (Crowther et al., 2011; Crowther et al., 2013), feed preferentially on certain fungal taxa (Ingham, 1992) or inhibit fungal activity in general (Warren and Bradford, 2012). Effects of insects on individual fungal species vary depending on the insects involved. In Sweden, Weslien et al. (2011) found Fomitopsis pinicola, a brown rot fungus, to be facilitated by a species of bark beetle but inhibited by a species of cerambycid beetle, for example. Overall effects on community metrics have been less studied but Müller et al. (2002) reported a negative correlation between the amount of damage caused by a bark beetle and fungal richness in Finland. While most efforts to explore such relationships have taken place in temperate regions where beetles dominate the woodfeeding insect community, there is a shortage of such studies from tropical or subtropical regions where termites are often the most numerous wood-dwelling insects (King et al., 2013) and can consume larger volumes of wood than

\footnotetext{
52 given their abundance, their movement of large amounts of soil into wood (Ulyshen and Wagner, 2013; Ulyshen et
} 
2012). The fecal material produced by termites and closely related wood cockroaches also appear to have antifungal properties (Chouvenc et al., 2013; Rosengaus et al., 2013) with extended disease resistance arising from growths of

57 Actinobacteria (Chouvenc et al., 2013). Most research in this area has focused on mechanisms by which termites are 58 protected from entomopathogenic fungi whereas no experimental efforts, to our knowledge, have explored how the microbial community at large is affected by these insects under natural conditions.

61 balance also remain unexplored. A number of researchers have proposed a link between invertebrate activity in decomposing wood and nutrient mineralization (Swift, 1977a, b; Swift and Boddy, 1984; Takamura, 2001;

63 Takamura and Kirton, 1999), and have further suggested these organisms may play a key role in releasing nutrients 64 immobilized in fungal tissues (Boddy and Watkinson, 1995). In addition, many wood-feeding insect species are 65 known to promote nitrogen fixation by endosymbiotic and free-living prokaryotes, with poorly understood effects on 66 forest nitrogen dynamics (Ulyshen, 2015). By facilitating the establishment of rot fungi or by improving aeration 67 (e.g., oxygen limitation constrains lignin degradation, see van der Wal et al. (2013)), invertebrates also have the potential to indirectly promote the breakdown of lignin, one of the most recalcitrant components of wood. Indeed, recent research found lignin content to be lower in logs colonized by phloem-feeding cerambycid beetles than in logs without them, suggesting these insects facilitated fungal colonization (Ulyshen et al., 2016).

73 microbial community characteristics (bacterial and fungal abundance, richness and composition) after two years in

74 both seasonally flooded and unflooded forests in the southeastern United States.

\section{Materials and Methods}

77

\subsection{Location and design}

79

80 This project was part of a larger study aimed at quantifying the contributions of arthropods to wood decomposition

81 in flooded and unflooded forests in the southeastern U.S. (for a complete description, see Ulyshen, 2014). In total,

82200 loblolly pine (Pinus taeda L.) logs measuring $55.9 \mathrm{~cm}$ long and $23.1 \pm 0.2 \mathrm{~cm}$ in diameter were cut from trees 
felled for this purpose. Half the logs were enclosed within stainless steel mesh bags ( $0.38 \mathrm{~mm}$ openings) to exclude termites and other insects whereas the other logs were left unenclosed. These treatments are hereafter referred to as

85 "protected" and "unprotected", respectively. Twenty widely separated (i.e., 0.1- $20 \mathrm{~km}$ apart) transects were established in mature mixed hardwood/pine forests in northern Mississippi (Oktibbeha, Noxubee and Winston counties). Half of these were situated near streams and flooded from late winter to early spring every year ("flooded") whereas the remainder were situated at slightly higher elevations and never flooded ("unflooded"). Each transect consisted of five plots separated by $10 \mathrm{~m}$. In early November 2010, each plot within each transect received one protected and one unprotected log. Those placed in the flooded forests were secured to a metal stake driven into the ground using metal wire and eye screws. One pair of logs was sampled every six months from each transect beginning and ending at 6 and 31 months, respectively, for a total of five sampling periods. The current study made use of the forty $\log$ s (i.e., 10 replicates for each combination of flood pattern and treatment) collected after 24 months in October 2012.

\subsection{Wood properties}

Data were collected on the nitrogen, lignin and water contents as well as Reticulitermes damage from the centers of the forty logs using the following methods. Each log was cut in half and one surface was cleaned of debris with an air hose and photographed. A 20 × 20 grid was superimposed over these images and the percentage of cells containing Reticulitermes damage was determined for each log. An electric drill was then used to drill six holes, each measuring $1 \mathrm{~cm}$ wide and $9 \mathrm{~cm}$ deep. One hole was drilled through the pith whereas the other five were drilled $4.5 \mathrm{~cm}$ away from the center hole in the shape of a pentagon. All the wood fragments created during the drilling for each log were collected and the water, nitrogen and lignin contents of these samples were determined. Water content was calculated as a percentage of wet weight after drying the samples at $102{ }^{\circ} \mathrm{C}$ for 24 hrs (i.e., wet weight - dry weight/wet weight) (Ulyshen et al., 2014). After grinding the dried samples into a powder using a Wiley mill, we measured N content (\%) using a Perkin Elmer Series II $2400 \mathrm{CHN}$ analyzer at the University of Georgia’s Chemical Analysis Laboratory. The lignin contents (\%) of these samples were determined (Complex Carbohydrate Research Center, University of Georgia) by pyrolysis-molecular beam mass spectrometry (pyrolysis-MBMS), a method used in previous studies to investigate chemical changes in decomposing wood (Kelley et al., 2002). For this analysis, 
111 each sample was prepared in duplicate by weighing about 2.5 to $3.5 \mathrm{mg}$ into a stainless metal cup, which was single112 shot pyrolyzed (Frontier Lab) at $500^{\circ} \mathrm{C}$. The volatile compounds were analyzed for lignin by molecular beam mass 113 spectrometer (Extrel Core Mass Spectrometers). The raw data were processed through The UnscramblerX 10.1

114 software to obtain the principal components and uncorrected lignin. A standard, NIST 8492 (Lignin content, 26.2\%) 115 was pyrolyzed and analyzed in the same manner and in the same batch as the unknown samples. The lignin values 116 from our samples were corrected based on this standard. The average lignin values for the duplicate samples were 117 then calculated and used in data analyses.

\subsection{Microbial community characteristics}

Estimates of bacterial abundance were made for each sample as follows. A weighed amount (0.15-0.2 g) of wood

122 from each sample was sonicated, diluted (100 or 1000-fold in distilled water), and spread onto petri dishes

123 containing R2A agar (Reasoner and Geldreich, 1985). We used R2A agar because it is less nutrient-rich than many

124 bacteria media (Reasoner and Geldreich, 1985) and may therefore be more suitable for bacteria associated with

125 nutrient-poor substrates like wood (Dr. Susan T. Bagley, personal communication). After several days of incubation 126 at $25^{\circ} \mathrm{C}$, the number of bacterial colonies visible on each plate was counted. Estimates for the number of colony

127 forming units per mg wood, hereafter referred to as "abundance", were then calculated for each sample.

To compare the richness and composition of bacterial and fungal communities between flood patterns and treatments, terminal restriction fragment length polymorphism (T-RFLP) data (i.e., the presence or absence of recognizable taxonomic units, hereafter referred to as "species") were collected. Although this method is known to overlook rare species and underestimates the richness of microbial communities, it is suitable for making the kinds 132 of general comparisons we sought in the current study (Bent et al., 2007; Blackwood et al., 2007; Fierer, 2007).

133 Two $\sim 0.1 \mathrm{~g}$ subsamples were taken from each sample of wood chips, placed in separate sample tubes containing 134 CTAB buffer and pulverized in a bead mill for two 3-minute cycles. After adding $200 \mu 1$ Tris-EDTA buffer with 20 $135 \mathrm{mg} / \mathrm{mL}$ lysozyme (to lyse bacterial cell walls), the samples were sonicated for 5 minutes. Bacterial and fungal DNA 136 were then extracted with a Machery Nagel Nucleospin Tissue Kit or Plant Kit (Machery Nagel, Easton, PA, USA) 137 and amplified using fluorescently-labeled 16S and ITS primers. Primers used for bacteria were forward: 5'- 
for fungi were forward: 5'- CTTGGTCATTTAGAGGAAGTAA-3' (Gardes and Bruns, 1993) and reverse: 5'-

140 TCCTCCGCTTATTGATATGC-3' (White et al., 1990). The forward primers of both sets were labeled with the

141 Beckman WellRed-D4 fluorescent tag. DNA amplification was carried out in an Eppendorff Mastercycler with the

142 following settings for bacteria (16S rRNA gene-based): an initial hot start at $94^{\circ} \mathrm{C}$ for five minutes $(10 \mu 1 \mathrm{DNA}$

143 template only), melting at $94^{\circ} \mathrm{C}$ for $45 \mathrm{sec}$, annealing at $57^{\circ} \mathrm{C}$ for $60 \mathrm{sec}$, and extension at $72^{\circ} \mathrm{C}$ for two minutes for

14430 cycles with a final extension at $72^{\circ} \mathrm{C}$ for seven minutes. The settings for fungi (ITS region-based) were: an initial

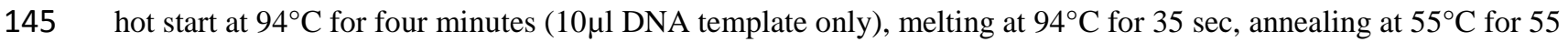

$146 \mathrm{sec}$, and extension at $72^{\circ} \mathrm{C}$ for one minute for 39 cycles with a final extension at $72^{\circ} \mathrm{C}$ for 10 minutes. After the

147 initial hot start, $40 \mu \mathrm{l}$ of a master mix containing (final concentration) $2 \mathrm{mM}$ Tris reaction buffer, $1.5 \mathrm{mM} \mathrm{MgCl}, 0.02$

$148 \mathrm{mM}$ of each primer, $0.02 \mathrm{mM}$ bovine serum albumin, $0.02 \mathrm{mM}$ deoxynucleotide triphosphates (dNTPs), ultra-pure

149 water, and $2.5 \mathrm{U}$ of Taq polymerase was added to each sample.

150 After verifying adequate amplification on 2\% agarose gels, restriction digests were carried out using $M s p$ I and

151 Taq I digest enzymes for bacterial and fungal DNA, respectively. After verifying adequate digestion on $2 \%$ agarose

152 gels, the samples were purified using a PCR cleanup kit (Machery Nagel, Easton, PA, USA). Samples (5 $\mu$ l) plus 40

$153 \mu$ l Sample Loading Solution (Beckman Coulter) and $0.8 \mu$ l of 600 bp Size Standard (Beckman Coulter) were

154 analyzed on a Beckman Coulter GeXP Capillary Electrophoresis system (Beckman Coulter, Fullerton, CA, USA) to

155 produce T-RFLP fragment data. The restriction fragment sizes and bin widths were estimated by the Beckman

156 Coulter software. To distinguish baseline noise from signal peaks, the software removed all peaks below an

157 arbitrarily chosen peak-height threshold value of 5000 Relative Fluorescent Units (RFU). Single peaks were not

158 deleted. Once the software generated the data matrix, all peaks and bins were visually checked and manually

159 adjusted if necessary. The final bacterial and fungal datasets consisted of matrices containing binary

160 presence/absence data. The number of "species" present in each sample was summed to determine species richness

161 and data matrices containing information on the presence or absence of each species were used to compare

162 community composition between flood pattern and treatments. 
We conducted two main analyses to investigate how termites influence wood properties [\% N, \% lignin, $\%$ water] and microbial communities [bacterial abundance, bacterial richness, fungal richness and community composition]. The first considered the complete dataset whereas the second was limited to unprotected logs only. For the complete dataset, we conducted two-way ANOVAs to compare response variables between treatments (i.e., protected and unprotected logs) and between flood patterns (flooded and unflooded). The interaction term was included in all models. For these models, data on $\% \mathrm{~N}$ and bacterial abundance were arcsine square root- and logtransformed, respectively, prior to analysis to improve normality. Otherwise untransformed data were used and only untransformed data are presented in figures. To compare among the four treatment $\times$ flood pattern combinations, we applied Tukey's multiple comparison test to least square means. To compare community composition between flood patterns and treatments, permutational multivariate analysis of variance (PERMANOVA) (Anderson, 2001) was carried out using PC-ORD. After eliminating any species present in fewer than three samples, the Jaccard distance measure was used on presence-absence data for bacteria and fungi separately and both tests involved 5000 permutations. To help visualize any compositional differences, nonmetric multidimensional scaling (NMDS) was carried out on the same datasets using the "slow and thorough" option in the autopilot mode of PC-ORD (Kruskal, 1964; Mather, 1976; McCune et al., 2002). The results are presented in ordination diagrams in which each experimental unit is depicted by a symbol and distances between symbols correspond to community dissimilarity (i.e., similarity decreases with increasing separation).

In our second set of analyses, limited to unprotected logs, we were interested in exploring how wood properties and microbial community characteristics varied with the amount of termite damage visible in crosssection. This was accomplished using ANCOVAs, with continuous and categorical variables being damage and flood pattern, respectively. In addition to the six main response variables considered in the analyses of the complete dataset, here we also used ordination scores from our NMDS analyses as metrics for bacterial and fungal community composition. In each case we used scores from the axis explaining the greatest amount of variation; axis $2\left(\mathrm{R}^{2}=0.51\right)$ for bacteria and axis $1\left(\mathrm{R}^{2}=0.46\right)$ for fungi. Because the interaction between damage and flood pattern was insignificant for all response variables, this term was excluded from the final models. As for the ANOVA models, data on $\% \mathrm{~N}$ and bacterial abundance were arcsine square root- and log-transformed, respectively, prior to analysis. Otherwise untransformed data were used and only untransformed data are presented in figures. 


\section{Results}

\subsection{Termite activity}

As intended, termites were completely excluded from all protected logs placed within the mesh bags.

By contrast, termites caused a considerable but highly variable amount of damage to unprotected logs in both flooded and unflooded forests. Only three of the 20 unprotected logs lacked visible damage in cross-section. Although termites caused almost twice as much damage, on average, in unflooded (42.2 \pm 8.1$)$ compared to flooded $(24.8 \pm 7.1)$ forests, the effect of flooding was not statistically significant $\left(\mathrm{F}_{1,18}=2.6, \mathrm{P}=0.1\right)$.

\subsection{Wood properties}

Based on ANOVA, $\% \mathrm{~N}$ and $\%$ lignin did not vary significantly between treatments or flood patterns and no interactions were detected (ANOVA results not shown but see Fig. 1). By contrast, \% water varied significantly between treatments $\left(\mathrm{F}_{1,36}=4.1, \mathrm{p}=0.05\right)$ and flood patterns $\left(\mathrm{F}_{1,36}=8.5, \mathrm{p}<0.01\right)$, being lower in protected logs and in unflooded forests. When compared for each flood pattern separately, the exclusion treatment did not significantly affect wood water content (Fig. 1). No significant differences were detected between wood properties and the amount of termite damage (Fig. 2).

\subsection{Microbial community characteristics}

214 Based on ANOVA, bacterial abundance varied significantly between treatments $\left(\mathrm{F}_{1,36}=16.3, \mathrm{p}<0.001\right)$ and between 215 flood patterns $\left(\mathrm{F}_{1,36}=24.0, \mathrm{p}<0.0001\right)$, being lower in protected logs and in flooded forests. The treatment effect was 216 only significant in unflooded forests based on Tukey's multiple comparison test (Fig. 1). Bacterial richness varied

217 significantly between flood patterns $\left(\mathrm{F}_{1,36}=5.0, \mathrm{p}=0.03\right)$ and there was a significant treatment $\times$ forest interaction

$218\left(\mathrm{~F}_{1,36}=4.6, \mathrm{p}<0.04\right)$. Bacterial richness tended to be higher in protected logs in flooded forests whereas the opposite 219 pattern was seen in unflooded forests (Fig. 1). Bacterial richness was significantly higher in unprotected logs in 220 unflooded forests compared to unprotected logs in flooded forests (Fig. 1). Fungal richness did not vary significantly 
221 between treatments or flood patterns and there was no significant interaction between these effects. Except for

222 bacterial nmds scores, no significant differences were detected between microbial communities and the amount of

223 termite damage (Fig. 2).

224 The results from PERMANOVA show bacteria communities, based on T-RFLP patterns, differed

225 significantly between treatments and flood patterns (Table 1). Fungal communities, based on T-RFLP patterns, also

226 differed between treatments and flood patterns and there was a significant interaction between the two factors (Table

227 1). Nonmetric multidimensional scaling yielded two dimensional solutions for both the bacterial and fungal datasets

228 and a final stress of 22.3 and 17.2, respectively. The differences in bacteria communities detected by

229 PERMANOVA are not easily visualized in the NMDS ordination (Fig. 3). The interaction between treatment and

230 flood pattern detected for fungal communities by PERMANOVA can be visualized, however. There is considerable

231 overlap between flood patterns for unprotected logs whereas the communities associated with protected logs formed

232 comparatively distinct groupings for each flood pattern (Fig. 3).

234 3. Discussion

235

236 Bacterial and fungal communities differed compositionally between logs protected or unprotected from termites.

237 Moreover, bacteria were significantly more abundant in unprotected logs, especially in unflooded forests where 238 termites were more active (Ulyshen, 2014). While these findings speak only to species capable of being cultured 239 under laboratory conditions, they suggest bacteria may be strongly favored by termite activity. Similarly, Chouvenc

240 et al. (2011) found the galleries of Reticulitermes flavipes (Kollar) to support diverse microbial assemblages

241 including 100-fold more bacteria than non-gallery material in laboratory arenas. Fungi were not common in the

242 galleries, possibly due to the fungistatic properties of termite fecal material used in gallery construction (Chouvenc

243 et al., 2008). More recently, Coptotermes formosanus Shiraki was shown to be protected from entomopathogens by

244 Actinobacteria (Streptomyces spp.) growing on the fecal nest material constructed by the species (Chouvenc et al.,

245 2013). The feces associated with the nests of the wood cockroach Cryptocercus punctulatus Scudder also appear to

246 provide protection against entomopathogenic fungi (Rosengaus et al., 2013). In addition to the defensive properties

247 of bacteria associated with feces, termites also reduce their exposure to entomopathogens through meticulous

248 grooming and the production of antimicrobial secretions (Rosengaus et al., 2011, and references therein). It remains 
unclear how these defensive mechanisms affect the broader fungal community or wood decomposition in general. In the current study, fungal richness was not significantly affected by the exclusion of insects and this was true in both

251 flooded and unflooded forests. We also did not see a significant relationship between fungal richness and the level of 252 termite damage visible in cross section.

That we did not find a reduction of nitrogen in unprotected logs is noteworthy considering the longstanding expectation (Swift, 1977a) and observation (Takamura, 2001) that insects accelerate nutrient mineralization from decomposing wood. It is possible that insects simultaneously act to promote nitrogen fixation while also increasing its mineralization with their net effect (i.e., the nitrogen content of wood) depending on the species involved, physical conditions and stage of decomposition (Ulyshen, 2015). Any influence of arthropods on cord-forming basidiomycetes may also alter the nitrogen content of decomposing wood as these organisms are capable of translocating nutrients from outlying sources (Boddy, 1999).

In addition to the effects of insect exclusion, our findings suggest seasonal flooding also affects microbial communities. Both bacterial and fungal communities exhibited compositional differences between flood patterns, for instance. For fungi, PERMANOVA detected a significant interaction between flood pattern and treatment. It appears from Fig. 3 that the fungal communities associated with protected logs in the two flood patterns were more 264 distinct than their unprotected counterparts. These findings suggest insects may dampen the effects of flooding on fungal community composition. Although not statistically significant, almost twice as much termite damage, on average, was reported from the centers of unprotected logs in unflooded forests compared to those from flooded

267 forests. This difference may explain why some of the between-treatment differences (e.g., bacterial abundance and richness) were stronger in unflooded compared to flooded forests.

270 used extensively in research on leaf litter decomposition. The current study represents the first use of exclusion 271 methods to explore the effects of wood-dwelling arthropods on microbial communities, however. The results from 272 alternative methods - such as opportunistic surveys of microbes occurring in the presence or absence of termites273 can be difficult to interpret. For example, Kirker et al. (2012) recently surveyed wood-inhabiting fungi from 274 naturally-occurring logs in the southeastern United States. Although the presence of Xylariales (white rot 275 ascomycetes) was strongly correlated with the absence of termites, it is difficult to know with certainty whether 276 termites were the inhibitors or the inhibited. Exclusion efforts have some important drawbacks as well, however. 
277 Most notably, the exclusion method itself has the potential to affect the response variable of interest beyond the 278 exclusion of the focal organisms. The most important mechanism by which an exclusion method is likely to affect 279 microbial communities is by altering moisture content. In our study, water content was slightly lower in protected 280 logs compared to unprotected logs in both flooded and unflooded forests. These differences were probably due to 281 the mesh bags and not termite exclusion as these insects appear to negatively affect wood water content (Fig. 2c, 282 Ulyshen et al., 2014). Because these differences were rather small, however, we consider the likelihood that our 283 conclusions were affected to be low. Moreover, our analysis of termite damage, which was limited to unprotected logs, lends additional support to our main conclusions. The relationships observed between $\%$ termite damage and the various wood properties and microbial community characteristics were largely consistent with our comparison of protected vs. unprotected logs. We therefore feel confident that the mesh bags allowed us to isolate the effects of termites as intended. We nevertheless acknowledge the possibility that mesh bags have the potential to confound results by altering the microclimate experienced by enclosed logs. We thus encourage future researchers interested in such questions to consider alternative physical exclusion methods such as open-topped pans with screened bottoms that are less likely to alter microclimate (Ulyshen et al., 2016)

Although many insect species were excluded by the mesh bags (Ulyshen, 2014), termites were probably

292 largely responsible for the differences we observed considering they are by far the dominant wood-feeding insects in our study region (Ulyshen et al., 2014). Previous studies have reported significant positive effects of termites on wood decomposition in our study area (Stoklosa et al., in press; Ulyshen, 2014; Ulyshen et al., 2016). While these organisms have the potential to affect wood decomposition through both direct (e.g., consumption and digestion) and indirect (e.g., altered microbial communities) means, the results from the current study suggest the former mechanism is more important in southeastern U.S. forests. Although both bacterial and fungal communities were

298 affected by termites and seasonal flooding, we found limited evidence that arthropods influence wood 299 decomposition by affecting microbial communities. Most notably, lignin content did not vary between treatments in flooded or unflooded forests. This is consistent with a recent study that also showed no effect of termites on lignin

301 content in decomposing logs belonging to a different tree species (Ulyshen et al., 2016). That study found a

302 significant decrease in lignin associated with beetle activity, however, suggesting that other insects active within decomposing wood may have indirect effects on the process. 


\section{Conclusions}

307 We sought to explore how subterranean termite activity in decomposing pine logs affects microbial communities in 308 both seasonally flooded and unflooded forests in the southeastern United States. We found the exclusion of termites 309 over the first two years of decomposition resulted in significant compositional differences in both bacterial and 310 fungal communities. Moreover, bacterial abundance was significantly greater for unprotected than protected logs.

311 Further research is needed to determine which species of bacteria and fungi are most influenced by termite activity

312 and to better explore the implications of these interactions for wood decomposition and related processes.

\section{Acknowledgments}

This research was supported by the USDA Forest Service, Southern Research Station. We thank the Noxubee

317 National Wildlife Refuge (contact: Henry Sansing) and the John W. Starr Memorial Forest (contact: Misty Booth)

318 for permission to carry out the study. We are also grateful to Craig Bell and Shawn Cooper (USDA FS) for their

319 help in the field. Finally, Erica Gibson, Chanda Davis, Kayla Chaney and Julianna Stratton (MSU students)

320 provided much-appreciated assistance in the lab. Finally, we thank Ryan Garrick (University of Mississippi), the

321 editor and three anonymous reviewers for commenting on an early version of the manuscript.

\section{References}

Adair, E.C., Parton, W.J., Del Grosso, S.J., Silver, W.L., Harmon, M.E., Hall, S.A., Burke, I.C., Hart, S.C., 2008. climates. Global Change Biology 14, 2636-2660.

46.

Bent, S.J., Pierson, J.D., Forney, L.J., 2007. Measuring species richness based on microbial community fingerprints: The emperor has no clothes. Applied and environmental microbiology 73, 2399-2401. 
Blackwood, C.B., Hudleston, D., Zak, D.R., Buyer, J.S., 2007. Interpreting ecological diversity indices applied to terminal restriction fragment length polymorphism data: Insights from simulated microbial communities. Applied and environmental microbiology 73, 5276-5283.

Boddy, L., 1999. Saprotrophic cord-forming fungi: Meeting the challenge of heterogeneous environments. Mycologia 91, 13-32.

Boddy, L., Watkinson, S.C., 1995. Wood decomposition, higher fungi, and their role in nutrient redistribution. Canadian Journal of Botany 73, S1377-S1383.

Bulmer, M.S., Denier, D., Velenovsky, J., Hamilton, C., 2012. A common antifungal defense strategy in Cryptocercus woodroaches and termites. Insectes Sociaux 59, 469-478.

Chouvenc, T., Efstathion, C.A., Elliott, M.L., Su, N.-Y., 2013. Extended disease resistance emerging from the faecal nest of a subterranean termite. Proceedings of the Royal Society B 280, 20131885

Chouvenc, T., Elliott, M.L., Su, N.-Y., 2011. Rich microbial community associated with the nest material of Reticulitermes flavipes (Isoptera: Rhinotermitidae). Florida Entomologist 94, 115-116.

Chouvenc, T., Su, N.-Y., Elliott, M.L., 2008. Interaction between the subterranean termite Reticulitermes flavipes (Isoptera: Rhinotermitidae) and the entomopathogenic fungus Metarhizium anisopliae in foraging areas. Journal of Economic Entomology 101, 885-893.

Crowther, T.W., Boddy, L., Jones, T.H., 2011. Outcomes of fungal interactions are determined by soil invertebrate grazers. Ecology Letters 14, 1134-1142.

Crowther, T.W., Stanton, D.W.G., Thomas, S.M., A'Bear, D., Hiscox, J., Jones, T.H., Voříšková, J., Baldrian, P., Boddy, L., 2013. Top-down control of soil fungal community composition by a globally distributed keystone consumer. Ecology 94, 2518-2528.

Fierer, N., 2007. Tilting at windmills: A response to a recent critique of terminal restriction fragment polymorphism data. Applied and environmental microbiology 73, 8041-8042.

Fukami, T., Dickie, I.A., Wilkie, J.P., Paulus, B.C., Park, D., Roberts, A., Buchanan, P.K., Allen, R.B., 2010. Assembly history dictates ecosystem functioning: evidence from wood decomposer communities. Ecology Letters 13, 675-684. 
Gardes, M., Bruns, T.D., 1993. ITS primers with enhanced specificity for Basidiomycetes - application to the identification of mycorrhizae and rusts. Molecular Ecology 2, 113-118.

Gholz, H.L., Wedin, D.A., Smitherman, S.M., Harmon, M.E., Parton, W.J., 2000. Long-term dynamics of pine and hardwood litter in contrasting environments: toward a global model of decomposition. Global Change Biology 6, 751-765.

Ingham, R.E., 1992. Interactions between invertebrates and fungi: Effects on nutrient availability, In: Carroll, G.C., Wicklow, D.T. (Eds.), The fungal community: Its organization and role in the ecosystem, 2nd ed. Marcel Dekker, Inc., New York, pp. 669-690.

Jacobsen, R.M., Birkemoe, T., Sverdrup-Thygeson, A., 2015. Priority effects of early successional insects influence late successional fungi in dead wood. Ecology and Evolution 5, 4896-4905.

Kelley, S.S., Jellison, J., Goodell, B., 2002. Use of NIR and pyrolysis-MBMS coupled with multivariate analysis for detecting the chemical changes associated with brown-rot biodegradation of spruce wood. FEMS Microbiology Letters 209, 107-111.

King, J.R., Warren, R.J., Bradford, J.B., 2013. Social insects dominate eastern US temperate hardwood forest macroinvertebrate communities in warmer regions. PLoS ONE 8, e75843.

Kirker, G.T., Wagner, T.L., Diehl, S.V., 2012. Relationship between wood-inhabiting fungi and Reticulitermes spp. in four forest habitats of northeastern Mississippi. International Biodeterioration and Biodegradation 72, $18-25$.

Kruskal, J.B., 1964. Nonmetric multidimensional scaling: a numerical method. Psychometrika 29, 115-129.

Leach, J.G., Orr, L.W., Christensen, C., 1937. Further studies on the interrelationship of insects and fungi in the deterioration of felled Norway pine logs. Journal of Agricultural Research 55, 129-140.

Liesack, W., Dunfield, P.F., 2004. T-RFLP Analysis, In: Spencer, J.F.T., Ragout de Spencer, A.L. (Eds.), Environmental Microbiology: Methods and Procedures. Humana Press, Totowa, NJ, pp. 23-37.

Liu, W., Schaefer, D., Qiao, L., Liu, X., 2013. What controls the variability of wood-decay rates? Forest Ecology and Management 310, 623-631.

Mather, P.M., 1976. Computational methods of multivariate analysis in physical geography. John Wil 
ey \& Sons, London.

McCune, B., Grace, J., Urban, D.L., 2002. Analysis of Ecological Communities. MjM Software Design, Gleneden Beach, Oregon.

Meentemeyer, V., 1978. Macroclimate and lignin control of litter decomposition rates. Ecology 59, 465-472.

Moorhead, D.L., Currie, W.S., Rastetter, E.B., Parton, W.J., Harmon, M.E., 1999. Climate and litter quality controls on decomposition: An analysis of modeling approaches. Global Biogeochemical Cycles 13, 575-589.

Müller, M.M., Varama, M., Heinonen, J., Hallaksela, A.-M., 2002. Influence of insects on the diversity of fungi in decaying spruce wood in managed and natural forests. Forest Ecology and Management 166, 165-181.

Reasoner, D.J., Geldreich, E.E., 1985. A new medium for the enumeration and subculture of bacteria from potable water. Applied and environmental microbiology 49, 1-7.

Rosengaus, R.B., Mead, K., Du Comb, W.S., Benson, R.W., Godoy, v.G., 2013. Nest sanitation through defecation: antifungal properties of wood cockroach feces. Naturwissenschaften 100, 1051-1059.

Rosengaus, R.B., Traniello, J.F.A., Bulmer, M.S., 2011. Ecology, behavior and evolution of disease resistance in termites, In: Bignell, D.E., Roisen, Y., Lo, N. (Eds.), Biology of termites: A modern synthesis. Springer, New York, pp. 165-191.

Stoklosa, A.M., Ulyshen, M.D., Fan, Z., Varner, M., Seibold, S., Müller, J., in press. Effects of mesh bag enclosure and termites on fine woody debris decomposition in a subtropical forest. Basic and Applied Ecology. DOI: 10.1016/j.baae.2016.03.001

Strid, Y., Schroeder, M., Lindahl, B., Ihrmark, K., Stenlid, J., 2014. Bark beetles have a decisive impact on fungal communities in Norway spruce stem sections. Fungal Ecology 7, 47-58.

Swift, M.J., 1977a. The ecology of wood decomposition. Science Progress 64, 175-199.

Swift, M.J., 1977b. The roles of fungi and animals in the immobilisation and release of nutrient elements from decomposing branch-wood, In: Lohm, U., Persson, T. (Eds.), Soil Organisms as Components of Ecosystems, pp. 193-202.

Swift, M.J., Boddy, L., 1984. Animal-Microbial Interactions in Wood Decomposition, In: Anderson, J.M., Rayner, A.D.M., Walton, D.W.H. (Eds.), Invertebrate-microbial interactions. Cambridge University Press, 
411 Takamura, K., 2001. Effects of termite exclusion on decay of heavy and light hardwood in a tropical rain forest of 412 peninsular Malaysia. Journal of Tropical Ecology 17, 541-548.

413 Takamura, K., Kirton, L.G., 1999. Effects of termite exclusion on decay of a high-density wood in tropical rain 414 forests of peninsular Malaysia. Pedobiologia 43, 289-296.

415 Trofymow, J.A., Moore, T.R., Titus, B., Prescott, C.E., Morrison, I., Siltanen, M., Smith, S., Fyles, J., Wein, R., Camiré, C., Duschene, L., Kozak, L., Kranabetter, M., Visser, S., 2002. Rates of litter decomposition over 6 years in Canadian forests: influence of litter quality and climate. Canadian Journal of Forest Research 32, 789-804.

Ulyshen, M.D., 2014. Interacting effects of insects and flooding on wood decomposition. PLoS ONE 9, e101867.

Ulyshen, M.D., 2015. Insect-mediated nitrogen dynamics in decomposing wood. Ecological Entomology 40 (Suppl. 1), 97-112.

Ulyshen, M.D., 2016. Wood decomposition as influenced by invertebrates. Biological Reviews 91, 70-85.

Ulyshen, M.D., Müller, J., Seibold, S., 2016. Bark coverage and insects influence wood decomposition: Direct and indirect effects. Applied Soil Ecology 105, 25-30.

Ulyshen, M.D., Wagner, T.L., 2013. Quantifying arthropod contributions to wood decay. Methods in Ecology and Evolution 4, 345-352.

Ulyshen, M.D., Wagner, T.L., Mulrooney, J.E., 2014. Contrasting effects of insect exclusion on wood loss in a temperate forest. Ecosphere 5, article 47.

van der Wal, A., Geydan, T.D., Kuyper, T.W., de Boer, W., 2013. A thready affair: linking fungal diversity and community dynamics to terrestrial decomposition dynamics. FEMS Microbial Ecology 37, 477-494.

van der Wal, A., Ottosson, E., de Boer, W., 2015. Neglected role of fungal community composition in explaining variation in wood decay rates. Ecology 96, 124-133.

Warren, R.J., Bradford, M.A., 2012. Ant colonization and coarse woody debris decomposition in temperate forests. Insectes Sociaux 59, 215-221. 
fungi colonizing decaying wood. Journal of Animal Ecology 80, 1155-1162. genes for phylogenetics, In: Innis, M.A., Gelfand, D.H., Sninsky, J.J., White, T.J. (Eds.), PCR Protocols: A Guide to Methods and Applications. Academic Press, San Diego, pp. 315-322. 
442 Table 1 Results from PERMANOVA for bacteria (top) and fungi (bottom). Treatment refers to whether logs were

443 protected or unprotected from insects. Flood pattern refers to whether logs were placed in flooded or unflooded

444 forests.

445

446

\begin{tabular}{|c|c|c|c|c|}
\hline & $\mathrm{df}$ & MS & $\mathrm{F}$ & $\mathrm{p}$ \\
\hline \multicolumn{5}{|l|}{ Bacteria } \\
\hline Treatment & 1 & 0.50 & 2.60 & $<0.001$ \\
\hline Flood pattern & 1 & 0.52 & 2.66 & $<0.001$ \\
\hline Treatment $\times$ Flood pattern & 1 & 0.28 & 1.43 & 0.09 \\
\hline Residual & 36 & 0.19 & & \\
\hline \multicolumn{5}{|l|}{ Fungi } \\
\hline Treatment & 1 & 1.60 & 9.14 & $<0.001$ \\
\hline Flood pattern & 1 & 0.88 & 5.02 & $<0.001$ \\
\hline Treatment $\times$ Flood pattern & 1 & 0.45 & 2.59 & 0.01 \\
\hline Residual & 36 & 0.17 & & \\
\hline
\end{tabular}

447

448 
Fig. 1. Mean \pm SE ( $n=10$, untransformed data) wood properties and microbial community characteristics at the centers of logs that were either protected or unprotected from termites for two years in seasonally flooded and

451 unflooded forests. Bars with different letters above them are significantly different $(\alpha<0.05)$ based on Tukey's

452 multiple comparison test. Bacterial abundance refers to the number of colony forming units per mg of wood.

453

Wood

Properties

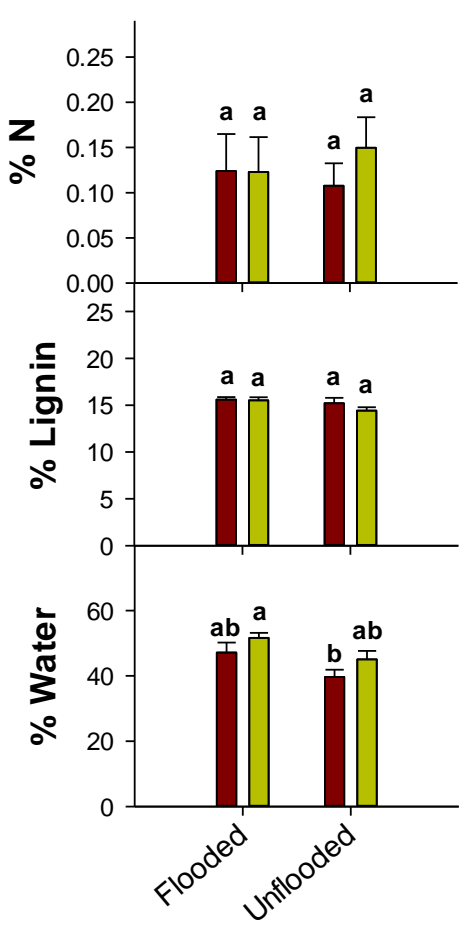

Forest type
Microbial

Communities

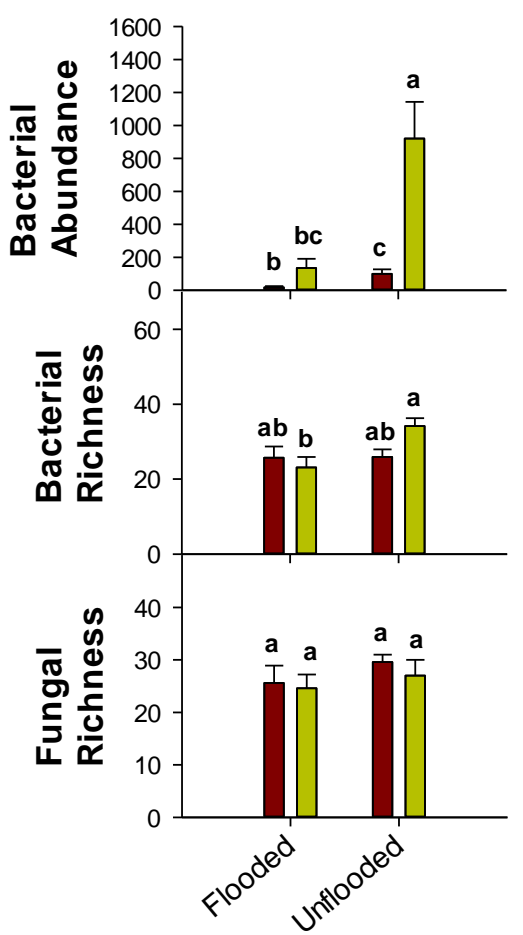

Forest type 
Fig. 2. Relationships between visible termite damage in unprotected logs and $\%$ nitrogen (a), \% lignin (b), \% water (c), bacterial abundance (d), bacterial richness (e), bacteria nmds scores for axis 2 (f), fungal richness ( $\mathrm{g}$ ) and fungi

457 nmds scores for axis 1 (h). Untransformed data are presented in every case. Symbols denote flooded (F) and

458 unflooded (U) forests. Note: significant differences between flood patterns or significant relationships with termite 459 damage are indicated within graphs, asterisks denote significance $(\alpha<0.05)$.

Wood

Properties

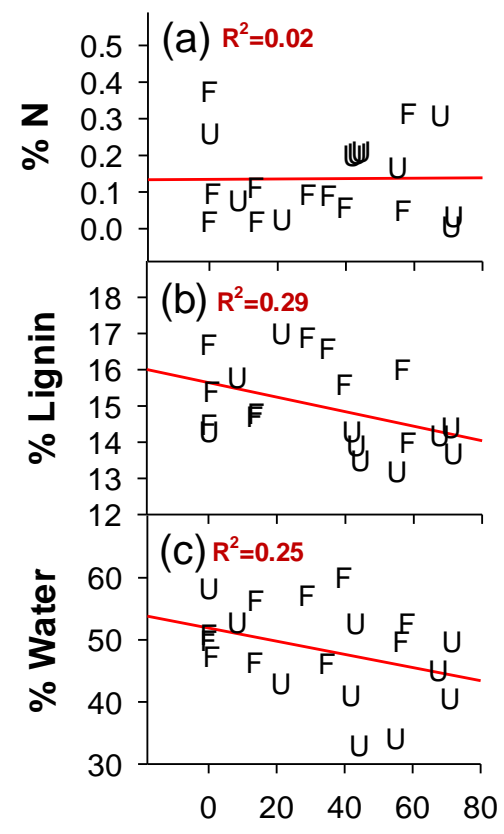

$\%$ Termite damage

\section{Bacterial Community}
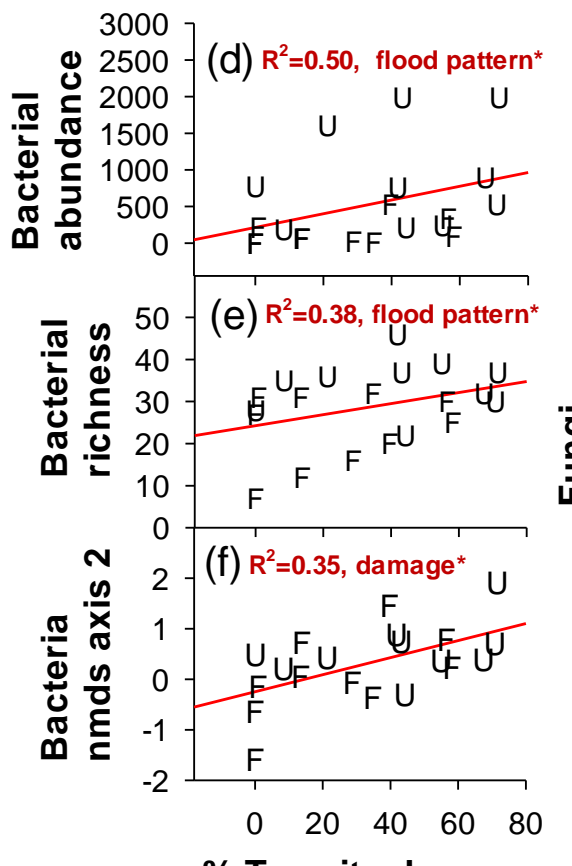

$\%$ Termite damage
Fungal Community

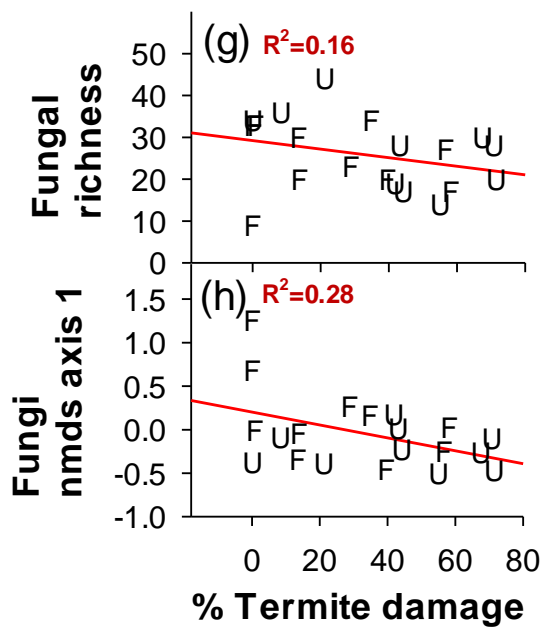




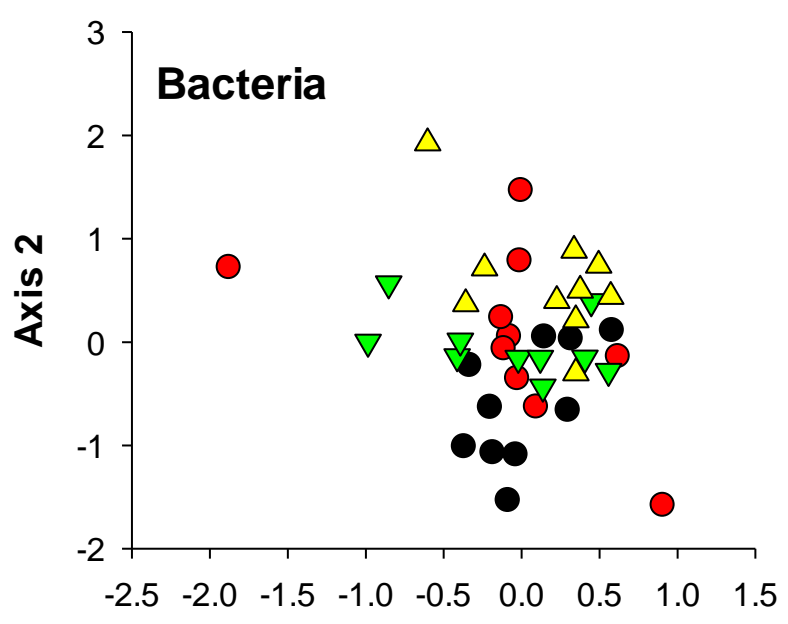

Axis 1

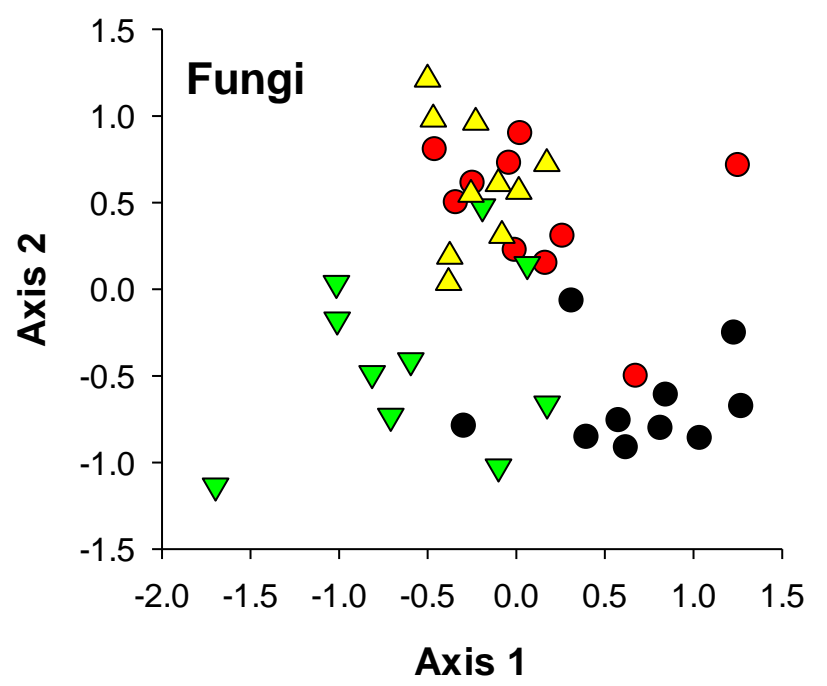

464
- Flooded, Protected
- Flooded, Unprotected
$\nabla \quad$ Unflooded, Protected
$\triangle$ Unflooded, Unprotected 